\title{
Physiotherapeutic treatment of arthralgias*
}

\author{
Tratamento fisioterapêutico das artralgias \\ Cascieli Miotto', Bárbara Kayser¹, Vinicius Dal Molin², Júlia Andréia Kummer³ ${ }^{3}$ Lia Mara Wibelinger ${ }^{4}$ \\ *Received from the Physiotherapy Course, University of Passo Fundo (UPF). Passo Fundo, RS.
}

\section{ABSTRACT}

BACKGROUND AND OBJECTIVES: Aging is a dynamic, progressive and unavoidable process bringing several physical and emotional changes. Arthralgia is one of the most limiting factors with regard to elderly people's functionality. This study aimed at reviewing the literature in search of possible non-pharmacological treatments which may contribute to improve the quality of life (QL) of arthralgia patients.

CONTENTS: LILACS, Medline, Pubmed, Bireme and Scielo databases were queried from 1998 to 2012. Among intervention methods to rehabilitate arthralgias in the elderly there are kinesiotherapy, thermotherapy, electrotherapy and hydrotherapy.

CONCLUSION: Hydrotherapy associated to kinesiotherapy may bring significantly positive results to the treatment of rheumatoid arthritis, osteoarthritis and osteoporosis.

Keywords: Arthralgia, Elderly, Physiotherapy.

\section{RESUMO}

JUSTIFICATIVA E OBJETIVOS: O envelhecimento é um processo dinâmico, progressivo e inevitável que traz consigo uma série de alterações, tanto físicas quanto emocionais. A artralgia é um dos fatores mais limitantes no que diz respeito à funcionalidade do idoso. $\mathrm{O}$ objetivo deste estudo foi realizar uma revisão na literatura em busca de possíveis tratamentos não farmacológicos que possam contribuir para melhorar a qualidade de vida (QV) dos pacientes portadores de artralgias.

CONTEÚDO: Para a realização do levantamento bibliográfico foram consultadas as bases de dados: LILACS, Medline, Pubmed, Bireme e Scielo, no período de 1998 a 2012. Dentre os métodos de intervenção utilizados na reabilitação das artralgias no idoso, estão a cinesioterapia, a termoterapia, a eletroterapia e a hidroterapia.

1. University of Passo Fundo (UPF); Colleger Pibic/UPF. Passo Fundo, RS, Brazil.

2. University of Passo Fundo (UPF); Colleger Pibic/Cnpq. Passo Fundo, RS, Brazil.

3. University of Passo Fundo (UPF); Colleger Probic/Fapergs. Passo Fundo, RS, Brazil.

4. University of Passo Fundo (UPF); Passo Fundo, RS, Brazil.

Submitted in January 02, 2013.

Accepted for publication in May 29, 2013.

Conflict of interests: None

Correspondence to:

Cascieli Miotto

Rua Léo Soares, 87/202 - Bairro Leonardo Ilha

99052-308 Passo Fundo, RS.

E-mail: cascielimiotto@hotmail.com
CONCLUSÁO: A hidroterapia associada à cinesioterapia pode trazer resultados significativamente positivos no tratamento da sintomatologia da artrite reumatoide, da osteoartrite e da osteoporose. Descritores: Artralgia, Fisioterapia, Idoso.

\section{INTRODUCTION}

Aging may be understood as a dynamic and progressive process characterized by morphological, functional, biochemical and psychological changes which determine progressive loss of ability to adapt to the environment, causing further vulnerability and incidence of pathological processes which may lead to death ${ }^{1}$. Daily pain is a major risk factor for the development of disabilities and older cohorts are more vulnerable ${ }^{2,3}$. Similar relationships were found for the risk of depression and mood disorders in patients with persistent pain ${ }^{3}$.

Pain may become a limiting and even disabling factor for patients and may affect any joint ${ }^{4,5}$. Several mechanisms and effects may be influenced by physiotherapy cognitive, physical and behavioral artifices, thus cooperating for the treatment of such patients ${ }^{6}$.

LILACS, Medline, Pubmed, Bireme and Scielo databases were searched from 1998 to 2012 using the keywords: arthralgia, joint pain, physiotherapy, elderly.

This study aimed at reviewing the literature in search for information about how physiotherapy may contribute for the treatment of arthralgias in the elderly.

\section{RHEUMATOID ARTHRITIS}

This is a chronic inflammatory disease affecting $0.5 \%$ to $1 \%$ of the world population, being more frequent among females ${ }^{7,8}$.

It may start at any age, being more common from 30 to 50 years of age. To date, its etiology is multifactorial, relating environmental, behavioral and genetic (HLA-DR4 and probably DR1 in some populations) factors, immune imbalance and neuroendocrine changes?.

It is a systemic inflammatory disorder which may affect several tissues and organs, such as skin, blood vessels, heart, lungs and muscles, but primarily affects joints, producing nonsuppurative inflammatory synovitis which in general evolves to joint cartilage destruction and joint anchylosis ${ }^{7}$.

Its clinical evolution may vary from short lasting moderate oligoarticular disease and minimal joint injury to irreversible progressive polyarthritis with marked functional loss ${ }^{10}$.

More commonly involved joints in the early stage are wrists, metacarpophalangeal, proximal interphalangeal of hands, meta- 
tarsophalangeal, shoulders and knees, with severe pain in the morning and at night, joint stiffness lasting 60 minutes or more in the morning and after long immobilization periods?

Treatment should be always focused on reaching minimal disease activity. So, it is critical to detect parameters which may indicate disease activity and prognosis to carry out an adequate treatment ${ }^{11}$.

Physiotherapy is important throughout the disease and aims at preserving and restoring general functional capacity, improving joint motility, muscle strength, resistance, flexibility and aerobic capacity. Physiotherapy treatment includes thermotherapy, electric stimulation and aquatic therapy ${ }^{12}$.

The effectiveness of aquatic therapy to treat AR was evaluated. We have selected 12 articles published between 2001 and 2005. It was observed that aquatic therapy seems to bring positive results to patients with this disease, both in physical and emotional terms ${ }^{13}$. Kinesiotherapy may include passive exercises in the early stages, and active, isometric and/or isotonic exercises. The objective of such exercises is to assure joint movement amplitude maintenance, restoration or gain, muscle strengthening and stretching, aerobic capacity and performance for specific skills ${ }^{14}$.

Most dynamic exercise programs follow the recommendations of the American College of Sports Medicine (ACSM) ${ }^{15}$. It is recommended that exercises last 20 minutes or more, be performed at least twice a week and lead to $60 \%$ increase in estimated cardiac output for the age, to have positive clinical effects without worsening disease activity or inducing pain. When dynamic exercises are compared to conventional joint rehabilitation programs, it is observed significant improvement in the quality of life of such patients ${ }^{16,17}$.

Aerobic activities, such as bicycle, walking, running, hydrogymnastics and swimming provide better cardiovascular fitness and may help preventing AR-related limitations ${ }^{14}$.

\section{OSTEOARTHRITIS}

Osteoarthritis (OA) is strongly associated to age and is the commonest form of rheumatic disease, affecting approximately $16 \%$ of the Brazilian population ${ }^{18}$.

It is the most frequent joint disease among the elderly with prevalence above $10 \%$ after 50 years of age and may bring major functional limitations ${ }^{19}$. It is the major cause of chronic musculoskeletal pain and mobility limitation among the elderly worldwide ${ }^{20}$. It may be defined as from its clinical characteristics, including affected joint pain, typically worsened with activity and relieved with rest; joint stiffness, especially in the morning and after periods of immobility; with formation of edema and deformity, instability, insecurity and functional and movements limitation ${ }^{21}$. Several factors, including biomechanics, genetics and inflammation affect the heterogeneous condition of the disease $\mathrm{e}^{22}$. The combination of such factors contributes to the symptoms of pain, stiffness and joint dysfunction. In this context, knee pain is the most frequent OA symptom, condition which is the major reason for chronic incapacity in the elderly population and a major source of disease-related disability. Pain severity varies widely, from no pain to immobilization and/or physical disability of the patient ${ }^{23}$.
Thermotherapy and electrotherapy are widely used, but there are few studies about their effectiveness for osteoarthritis ${ }^{24}$.

Consensus on managing OA recommend exercises for pain and functional improvement $\mathrm{t}^{24,25}$.

A randomized study ${ }^{26}$ evaluating the effect of strengthening femoral quadriceps on functional capacity and knee OA symptoms using the Timed Up and Go (TUG) test, the Western Ontario and McMaster Universities Osteoarthritis Index (WOMAC) questionnaire and Lesquesne Index has concluded that quadriceps strengthening exercises are effective to improve pain, function and stiffness in patients with this disease.

Aquatic therapy may be considered a major therapeutic intervention to treat osteoarthritis. Water physical and physiological properties enable exercises hardly performed on the ground and which, associated to better movement amplitude and high water temperature, increase joint mobility, muscle control and resistance, relieving pain and accelerating functional recovery process ${ }^{27}$.

With regard to electrotherapy, a randomized, placebo-controlled and double-blind clinical trial has shown that low intensity laser therapy was effective, in the short term, to improve pain and function of knee OA patients ${ }^{28}$.

A randomized, prospective and blind study ${ }^{29}$ has compared physiotherapy protocols involving kinesiotherapy, cryotherapy and short waves in knee OA patients and has observed that the best protocol was that involving ice application and kinesiotherapy for analgesia; however there has been no amplitude, flexibility and strength gain associated to cryotherapy.

\section{OSTEOPOROSIS}

Among most frequent chronic diseases in the elderly, osteoporosis has been pointed as a priority of the world public health due to its high prevalence and effects on physical and psychosocial health of the elderly ${ }^{1}$.

Osteoporosis is a systemic disease characterized by decreased bone mineral density (BMD), with deterioration of bone tissue microarchitecture, resulting in loss of resistance and increased risk for brittleness fractures, especially in spine, hips and wrists ${ }^{30}$. Physical activity may, among other factors, decrease pain ${ }^{31}$, decrease the use of analgesics ${ }^{32}$ and improve quality of life (QL) of osteoporosis patients ${ }^{31}$.

Authors advocate that just exercises like walking are not so relevant to treat osteoporosis because bones are not stressed to the point of increasing bone mass ${ }^{32-34}$. So, specific and regular physical exercises allow the maintenance of physical independence to perform daily activities (DA) and improve $\mathrm{QL}^{35}$.

A systematic review of the effects of intervention with resistance training on muscle strength and bone mineral density in sites with greater occurrence of fractures in post-menopausal women, and involving controlled, randomized and meta analysis trials, has shown that resistance training may be able to promote stimulation to improve muscle strength and bone formation ${ }^{36}$.

When regularly practiced, resistance training may improve muscle strength, with positive effects on protection against falls, in addition to the effective stimulation for bone mass increase ${ }^{37}$, thus influencing risk factors favoring osteoporosis. 


\section{CONCLUSION}

There are several physiotherapy resources to treat arthralgias, with greater emphasis to hydrotherapy associated to kinesiotherapy for osteoarthritis and rheumatoid arthritis patients. For osteoporosis, physical activity is the most recommended resource. However, further studies are needed aiming at enhancing the knowledge in the area and offering patients a more effective treatment.

\section{REFERENCES}

1. Carvalho CMRG, Fonseca CGC, Pedrosa JI. Educação para a saúde em osteoporose com idosos de um programa universitário: repercussôes. Cad Saúde Pública. 2004;20(3): 719-26.

2. Silva MC, Fassa AG, Valle NC. Chronic low back pain in a Southern Brazilian adult population: prevalence and associated factors. Cad Saúde Pública. 2004;20(2):377-85.

3. Brennan DS, Singh KA. Dietary, self-reported oral health and socio-demographic predictors of general health status among older adults. J Nutr Health Aging. 2012;16(5):437-41

4. Melo Junior CF, Saito OC, Guimarães Filho HA. Avaliaçấo ultrassonográfica dos distúrbios intracapsulares temporomandibulares. Radiol Bras. 2011;44(6):355-9.

5. Lima CMAO, Ribeiro EB, Coutinho EPD, et al. Síndrome do impacto do tornozelo na ressonância magnética: ensaio iconográfico. Radiol Bras. 2010;43(1):53-7.

6. Gosling AP. Mecanismos de ação e efeitos da fisioterapia no tratamento da dor. Rev Dor. 2013;13(1):65-70.

7. Rantalaiho V, Kautiainen H, Virta L, et al. Trends in treatment strategies and the usage of different disease-modifying anti-rheumatic drugs in early rheumatoid arthritis in Finland. Results from a nationwide register in 2000-2007. Scand J Rheumatol, 2011;40(1):16-21.

8. Hamilton JA, Tak PP. The dynamics of macrophage lineage populations in inflammatory and autoimmune diseases. Arthritis Rheum. 2009;60(5):1210-21.

9. Sokka T, Makinen H. Remission makes its way to rheumatology. Arthritis Res Ther. 2010;12(4):129.

10. Möttönen T, Mäkinen H, Puolakka K. The goal for the treatment of rheumatoid arthritis should be remission. Duodecim. 2010;126(12):1457-64.

11. Klareskog L, Catrina AI, Paget S. Rheumatoid arthritis. Lancet. 2009;373(9664):659-72.

12. Kavuncu V, Evcik D. Physiotherapy in rheumatoid arthritis. MedGenMed. 2004;6(2):3.

13. Gimenes OR, Concuruto A, Okubo TS, et al. Análise crítica da efetividade da fisioterapia aquática na artrite reumatoide. Fisioterapia Ser. 2010;5(3):175-9.

14. Vliet Vlieland TP. Rehabilitation of people with rheumatoid arthritis. Best Pract Res Clin Rheumatol. 2003;17(5):847-61.

15. Garber CE, Blissmer B, Deschenes MR, et al. American College of Sports Medicine position stand. Quantity and quality of exercise for developing and maintaining cardiorespiratory, musculoskeletal, and neuromotor fitness in apparently healthy adults: guidance for prescribing exercise. Med Sci Sports Exerc. 2011;43(7):1334-59.

16. Baillet A, Payraud E, Niderprim VA, et al. A dynamic exercise programme to improve patients' disability in rheumatoid arthritis: a prospective randomized controlled trial. Rheumatology. 2009;48(4):410-5.

17. Munneke M, de Jong Z, Zwinderman AH, et al. Effect of a high-intensity weight-bearing exercise program on radiologic damage progression of the large joints in subgroups of patients with rheumatoid arthritis. Arthritis Rheum. 2005;53(3):410-7.

18. McDonough CM, Jette AM. The contribution of osteoarthritis to functional limitations and disability. Clin Geriatr Med. 2010;26(3):387-99.

19. Bedson J, Jordan K, Croft P. The prevalence and history of knee osteoarthritis in general practice: a case-control study. Fam Pract. 2005;22(1):103-8.

20. Thomas E, Peat G, Harris L, et al. The prevalence of pain and pain interference in a general population of older adults: cross-sectional findings from the North Staffordshire Osteoarthritis Project (NorStOP). Pain. 2004;110(1-2):361-8.

21. Fellet A, Fellet AJ, Fellet L. Osteoartrose: Uma Revisão. Rev Bras Med 2007; 64:55-61.

22. Peterfy CG, Gold G, Eckstein F, et al. MRI protocols for whole-organ assessment of the knee in osteoarthritis. Osteoarthritis Cartilage. 2006;14(Suppl A):A95-111.

23. Clauw DJ, Witter J. Pain and rheumatology: thinking outside the joint. Arthritis Rheum. 2009;60(2):321-4.

24. Coimbra IB, Pastor EH, Greve JMD, et al. Consenso brasileiro para o tratamento da osteoartrite (artrose). Rev Bras Reumatol. 2002;42(6):371-4.

25. Recommendations for the medical management of osteoarthritis of the hip and knee Arthritis Rheum. 2000;43(9):1905-15.

26. Oliveira AMI, Peccin MS, Silva KNG, et al. Impacto dos exercícios na capacidade funcional e dor em pacientes com osteoartrite de joelhos: ensaio clínico randomizado. Rev Bras Reumatol. 2012;52(6):870-82.

27. Aguiar Júnior AS, Gereminas VC. Efeitos da hidroterapia na osteoartrose de joelho. Fisio Magazine. 2003;1(1):12-5.

28. Fukuda, VO, Fukuda TY, Guimarāes M, et al. Eficácia a curto prazo do laser de baixa intensidade em pacientes com osteoartrite do joelho: ensaio clínico aleatório, placebo-controlado e duplo-cego. Rev Bras Ortop. 2011;46(5):526-33.

29. Silva ALP, Imoto DM, Croci AT. Estudo comparativo entre a aplicaçáo de crioterapia, cinesioterapia e ondas curtas no tratamento da osteoartrite de joelho. Acta Ortop Bras. 2007;15(4):204-9.

30. Herrmann M, Umanskaya N, Wildemann B, et al. Stimulation of osteoblast activity by homocysteine. J Cell Mol Med. 2008;12(4):1205-10.

31. Granito RN, Renno ACM, Aveiro MC, et al. Efeitos de um programa de atividade física na postura hipercifótica torácica, na dorsalgia e na qualidade de vida de mulheres com osteoporose. Rev Bras Fisioter. 2004;8(3):231-7.

32. Navega MT, Aveiro MC, Oishi J. A influência de um programa de atividade física na qualidade de vida de mulheres com osteoporose. Fisioter Mov. 2006;19(4):25-32.

33. Bergström I, Landgren B, Brinck J, et al. Physical training preserves bone mineral density in postmenopausal women with forearm fractures and low bone mineral density. Osteoporos Int. 2008;19(2):177-83.

34. Vaillant J, Vuillerme N, Martigné P, et al. Balance, aging, and osteoporosis: effects of cognitive exercises combined with physiotherapy. Joint Bone Spine. 2006;73(4):414-8.

35. Navega MT, Aveiro MC, Oishi J. Alongamento, caminhada e fortalecimento dos músculos da coxa: um programa de atividade física para mulheres com osteoporose. Ver Bras Fisioter. 2003;7(3):261-7.

36. Jovine MS, Buchalla CM, Santarém EMM, et al. Efeito do treinamento resistido sobre a osteoporose após a menopausa: estudo de atualizaçăo. Rev Bras Epidemiol. 2006;9(4): 493-505.

37. Greendale GA, Huang MH, Wang Y, et al. Sport and home physical activity are independently associated with bone density. Med Sci Sports Exerc. 2003;35(3):506-12. 